\title{
Species specific effect of nest-box cleaning on settlement selection decisions in an artificial colony system
}

\author{
Péter Fehérvári ${ }^{*}$, Imre SÁndor Piross² ${ }^{2}$, LÁszló Kotymán ${ }^{3}$, \\ Szabolcs Solt ${ }^{4}$, Éva Horváth ${ }^{4}$ \& Péter Palatitz ${ }^{4}$
}

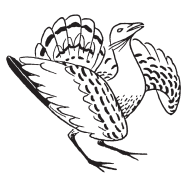

Péter Fehérvári, Imre Sándor Piross, László Kotymán, Szabolcs Solt, Éva Horváth \& Péter Palatitz 2015. Species specific effect of nest-box cleaning on settlement selection decisions in an artificial colony system. - Ornis Hungarica 23(1): 66-76.

have to make. Free ranging solitary Kestrels may use public information derived from leftover pellets and prey remnants from previous conspecific breeding attempts to assess location quality. However, this information may also indicate potentially higher nestling ectoparasite load. In colonies where habitat quality is similar for all available nests, the only information of previous nest usage may reflect expected future parasite pressure. In this study we explored whether Kestrels, Red-footed Falcons and Jackdaws rely on nest-material consisting of pellets and prey remnants when choosing a nest in a multi species artificial colony system. We also assessed potential effects of these decisions on reproductive success. We randomly selected and cleaned half $(\mathrm{n}=102)$ of all available nest-boxes in each of the studied 4 colonies before the breeding season. We then monitored occupancy, egg-laying date, hatching and fledging success. In case of Red-footed Falcons, we also acquired adult age and nestling condition data. Our results show that Kestrels were more likely to breed in uncleaned nest-boxes, however, eggs laid in cleaned nest-boxes were more likely to develop into fledged nestlings. There was a weak indication that lower hatching rate was responsible for this effect, rather than increased parasite load. Nest box cleaning had no effect on measured variables in case of Red-footed Falcons and Jackdaws. Colonial breeding of Kestrels, the only species to react to nest-box cleaning, is rare and is probably a consequence of extreme nest-site shortage in our study site. We conclude that Kestrels are not adapted to interpret the information carried by pellets and prey-remnants in colony nest-boxes.

Keywords: Falco tinnunculus, Falco vespertinus, Corvus monedula, public information, nest site choice

Összefoglalás A költőterület- és költőhelyválasztás az egyik legfontosabb döntés nem fészeképítő madárfajok esetén. Egy korábbi vizsgálat kimutatta, hogy szoliter vörös vércsék a fajtársaik által hagyott nyomokat (köpetek, táplálékmaradvány) figyelembe veszik a költőhely választásakor, mint a költőterület minőségére vonatkozó publikus információt, és korábban költenek azokon a helyeken, ahol fajtársaik nyomai fellelhetők. Annak ellenére teszik mindezt, hogy a fiókák potenciális ektoparazita fertőzöttsége magasabb azokon a helyeken, ahol korábban költés volt. A kolóniákban azonban, ahol az élőhely minősége minden fészek esetében hasonló, ez az információforrás elsősorban a potenciális ektoparazita terheltséget tükrözi. Ebben a vizsgálatban mesterséges kolóniákban vizsgáltuk vörös vércsék, kék vércsék és csókák fészekválasztását attól függően, hogy található-e benne korábbi költésekből származó köpet és egyéb táplálékmaradvány. Eredményeink szerint csak a vörös vércsére volt hatással a költőládák tisztasága. Ezeket nagyobb arányban foglalták el, azonban a fiókák kisebb valószínüséggel repültek ki a takarítatlan ládákból. Úgy tünik azonban, hogy ez a veszteség inkább az alacsonyabb kelési siker következménye, és nem a magasabb ektoparazita nyomás okozza. A vörös vércse jellemzősen nem telepesen költ, a vizsgálati területen telepes költését feltehetőleg az extrém fészkelőhely-hiány okozza. Valószínüsítjük, hogy a vörös vércsék nem adaptálódtak megfelelően a telepeken lévő fészkekben látható maradványok hordozta információ felhasználáshoz. 


\begin{abstract}
${ }^{1}$ Department of Zoology, Hungarian Natural History Museum, 1088 Budapest, Baross utca 13., Hungary, e-mail: fpeter17@gmail.com

${ }^{2}$ Department of Biomathematics and Informatics, Szent István University, Faculty of Veterinary Science, 1078 Budapest, István utca 2., Hungary

${ }^{3}$ MME/BirdLife Hungary, Red-footed Falcon Conservation Working Group, 1121 Budapest, Költö utca 21., Hungary ${ }^{4}$ Körös-Maros National Park Directorate, 5440 Szarvas, Anna liget 1., Hungary

*corresponding author
\end{abstract}

\section{Introduction}

Selecting breeding habitat and breeding site within has a crucial effect on realized individual fitness of birds (e.g. Valkama \& Korpimäki 1999, Serrano et al. 2005, Arlt \& Pärt 2007, Kasprzykowski 2008). Settlement decision of prospecting breeders has to incorporate habitat quality, potential presence of predators, and nest site quality; such as orientation, exposure and potential parasite load. Acquiring a priori information before settlement is pivotal, and may rely on various sources. An individual may lean on recent personal experience such as food availability and observation of predators or on past experience, realized as high probability of philopatry. There is increasing evidence that settlers may also use public information such as reproductive success (Danchin \& Wagner 1997, Aparicio et al. 2007, Boulinier et al. 2008) or the historic presence of conspecifics (Sumasgutner et al. 2014), and other species (Parejo 2004) with similar ecological needs. The advantage of using cues that reflect conspecific performance is that they provide insight into the net effects of various factors influencing reproductive success (Danchin et al. 2004). Of these, potential ectoparasite load on offspring may be a key component of settlement decisions of prospecting breeders as it may influence nestling mortality (Wimberger 1984, Richner et al. 1993) affect parental care investment (Richner et al. 1993, Tripet \& Richner 1997) and reproductive success (Ontiveros et al. 2008). Colonial species may experience higher prevalence of ectoparasites compared to territorial breeders (Rózsa et al. 1996, Brown \& Brown 2004) and, thus constitute one of the main costs of coloniality (Brown \& Brown 1986).

Sumasgutner et al. (2014) have previously shown that settlement decisions of free ranging solitary breeding Kestrels (Falco tinnunculus) may rely on public information deriving from residual nest-material, pellets and prey remains left from previous breeding attempts of conspecifics. The birds did this despite the lower prevalence rate of a heamatophagus Carnid Fly (Carnus hemapterus) in nests where the nest material was cleaned prior to breeding. Apparently, assessing habitat quality via public information was more important than higher risk of ectoparasite loads for these solitary nesting falcons. The same ectoparasite is commonly found on colonial raptors including, Lesser Kestrels (Calabuig et al. 2010), and Red-footed Falcons (Falco vespertinus) (Brake 2011, pers. obs.). These flies are presumed to use the nest substrate to lay eggs, and the larvae feed on organic matter in the nest material before developing into adults or overwintering as pupae. The mass emergence of adult flies from the substrate often coincides with a specific age of the host species and predominantly feed on nestling blood (Roulin 1998, Roulin et al. 2003). Adult flies have two distinct life forms, the first when individuals locate new host nests (transmissive form), and the second when 
they lose their wings and remain in the newly colonized brood (Capelle \& Whitworth 1973). Effective horizontal transmission of the transmissive form in areas with low internest distance is probably the main reason of high prevalence of flies in colonial species (Liker et al. 2001).

This set-up allowed us to test with an in situ experiment whether the two falcon species and Jackdaws (Corvus monedula) that are also exploting these boxes, cue on pellets and prey remnants as a source of public information on potential future ectoparasite load on nestlings. We hypothesized that pairs of all species will select for cleaned boxes by earlier egg laying and by higher probability of occupancy. Furthermore, we tested potential effects of cleaning on reproductive success parameters of all species and also on the condition of Red-footed Falcon nestlings. Testing these hypotheses may yield intriguing insight into settlement decision making of prospecting breeders and also allow us to assess the importance of nest-box cleaning activities. Nest-box maintenance of Red-footed Falcon colonies is an important and highly resource- and time-consuming activity in the conservation management of this species. Thus evaluating the necessity of annual maintenance may allow us a better allocation of limited resources available for active conservation measures.

\section{Materials and Methods}

\section{Study site and nest boxes}

The study was carried out in 2013 at an artificial colony system located in the Vásárhelyi Plains, Hungary (see Kotymán et al. 2015 for details). Here, a total of 251 nest-boxes were available in 4 larger colonies, several smaller clusters and as platforms for solitary breeding. Initially, we used a stratified randomizing procedure to select $50 \%$ of available nest-boxes in each artificial colony. The selection procedure considered the withincolony location of the boxes, thus selected boxes were not aggregated in either the centre or the edge of colonies. The selected boxes were cleaned of all nest materials by scraping all remaining prey items and pellets completely, and were filled with hay. Providing some sort of breeding substrate is necessary as nest-boxes are often tilted to some degree, thus the eggs may roll into the corners if the birds start incubating on the flat surface of the box. We chose hay as the provided nest-material in cleaned boxes as it differs both visually and in texture from the typical pellet bedding remaining in the uncleaned boxes. Nest-box design may have an impact on various parameters of reproduction (Kotymán et al. 2015), therefore we only involved the most common box type into our analyses. We also excluded smaller colonies and solitary boxes leaving a sample size of 102 cleaned and 135 untreated nest-boxes.

\section{Assessing egg laying date, occupancy rate and breeding success parameters}

In 2013, we recorded the species, the number of breeding pairs, first egg laying date (Julian date), clutch size, hatching and fledging success for all species breeding in the study area. sequential nesting during the same breeding season of various species in the same box is not uncommon in this area. Therefore, we only used the data of the first breeders of all species in case of both cleaned and uncleaned boxes and excluded any subsequent clutches. Our primary focus was on assessing the reproductive parameters of Red-footed Falcons and Kestrels, thus the timing and frequency 
of nest inspections was optimized to allow collection of precise data on these species. Long-eared Owls (Asio otus) and Jackdaws initiate breeding earlier than these two falcon species. The relatively low number of nest inspections from this period hindered assessing precise egg laying date for Jackdaws. Thus, to avoid this type of bias we calculated egg laying week of the year for this species. We also excluded all Jackdaw clutches where the low number of nest inspections did not allow to assess fledging status of all hatched nestlings.

\section{Individual experience and nestling condition in Red-footed Falcons}

A considerable proportion of Red-footed Falcons, breeding at the study site are marked with individually coded colour rings. We identified marked individuals breeding in the focal boxes with spotting scopes and camera traps. Age often correlates with individual quality in raptors (e.g. Penteriani et al. 2003, Espie et al. 2004), and also with competitive dominance in nest sight selection in a similar sibling species, the Lesser Kestrel (Falco naumanni) (Serrano et al. 2007). Therefore we used adult age as a measure of individual quality, with older birds having supposedly higher recruiting capability to a nest-site of choice. All nestlings of Red-footed Falcons were ringed and wing-bone, body mass and various other morphometric measurements were recorded. We used the residuals of age by body mass and age by wing length regressions as age-independent measures of nestling condition.

\section{Statistical analyses}

We used linear models to test whether egg laying date differs for cleaned and un- cleaned nest boxes in case of all studied species. General Linear Models (GLM) with binomial distribution and logit link functions were fitted to assess differences in occupancy rate and fledging success for all species. For clutch size we used GLMs with a Poisson distribution and a log link function (Faraway 2006). For nestling condition (measured as age-independent body mass and wing length) we used linear mixed effects models (LME), where nest-box identity was used as a random factor (Pinheiro \& Bates 2000). In general, we used nest-box treatment and colony identity as explanatory variables in case of all models fitted. We excluded colony effect whenever it was not significant, and used Akaike Information Criterion (linear models) decrease in deviance (GLM), and the likelihood ratio tests to compare model performance (Faraway 2006) of these reduced models. If the colony effect was significant we indicated it in the outputs, however, to allow concise presentation of reports we provide details only on the effect of cleaned boxes on analysed response variables. All analyses were carried out using R 3.2.0 (R Core Team 2015).

\section{Results}

Overall, $65 \%$ of cleaned and $67 \%$ of uncleaned boxes were used by the four most common species breeding in the colonies. Only two pairs of Long-eared Owls bred in the studied boxes, therefore we excluded this species from further analyses. We found no difference in the timing of breeding in case of Jackdaws, Kestrels and Red-footed Falcons (Table 1). The probability of occupancy was significantly larger for uncleaned nest boxes for Kestrels, but not for Red-footed Falcons and Jackdaws (Figure 1, Table 2). 


\begin{tabular}{|l|c|c|c|c|c|}
\hline Species & $\mathbf{N}$ & Estimate & SE & t-value & p-value \\
\hline Kestrel & $12 / 10$ & 4.42 & 7.4 & 0.6 & 0.56 \\
\hline Red-footed Falcon* & $30 / 27$ & -3.23 & 3.16 & -1.02 & 0.31 \\
\hline
\end{tabular}

*significant effect of colony identity

Table 1. Linear model parameter estimates for egg laying date in cleaned versus uncleaned boxes measured as week of the year for Jackdaws and Julian days for Kestrels and Red-footed Falcons. $\mathrm{N}$ denotes the number of observations in uncleaned/cleaned nest-boxes. We found no significant effect of nest-box cleaning on the timing of breeding in any of the studied species

1. táblázat A ládatakarítás költéskezdésre gyakorolt hatását leíró lineáris modell paraméter becslései. Csókák esetében az év hetével, míg a többi faj esetén az évnappal számoltunk. Az $\mathrm{N}$ a költések száma a takarítatlan/takarított ládákban. Nem találtunk szignifikáns eltérést a költések időzítésében a takarított és a nem takarított ládákban egyik faj esetében sem

\begin{tabular}{|l|c|c|c|c|c|}
\hline Species & $\mathbf{N}$ & Estimate & SE & z-value & $\operatorname{Pr}(>|\mathbf{z}|)$ \\
\hline Jackdaw & $23 / 18$ & 0.287 & 0.31 & 0.92 & 0.36 \\
\hline Kestrel & $37 / 21$ & -0.56 & 0.27 & -2.07 & 0.03 \\
\hline Red-footed Falcon & $30 / 27$ & -0.1 & 0.26 & -0.40 & 0.70 \\
\hline
\end{tabular}

Table 2. Binomial GLM parameter estimates fitted on the probability of occupying a cleaned nestbox. $\mathrm{N}$ denotes the number of observations in uncleaned/cleaned nest-boxes. Kestrels were significantly more likely to choose an uncleaned nest box

2. táblázat Binomiális GLM paraméter becslései a fészkelés valószínűségére. Az N a költések számát mutatja a takarítatlan/takarított ládákban. A vörös vércsék szignifikánsan magasabb arányban költöttek a nem takarított ládákban, míg a többi faj esetében nem találtunk hasonló mintázatot

\begin{tabular}{|l|c|c|c|c|c|}
\hline Species & $\mathbf{N}$ & Estimate & SE & z-value & $\operatorname{Pr}(>|\mathbf{z}|)$ \\
\hline Kestrel & $37 / 21$ & -0.1 & 0.08 & -1.35 & 0.18 \\
\hline Red-footed Falcon* & $30 / 27$ & -0.07 & 0.1 & -0.72 & 0.48 \\
\hline
\end{tabular}

*significant effect of colony identity

Table 3. Poisson GLM parameter estimated fitted on clutch size in uncleaned and cleaned nestboxes. $\mathrm{N}$ denotes the number of clutches in uncleaned/cleaned nest-boxes. Clutch size was not affected by nest-box cleaning in neither of the species

3. táblázat Poisson GLM paraméter becslései a fészekalj méretre a takarított és a takarítatlan ládákban. Az N a mintaelemszámot mutatja a takarítatlan/takarított ládákban. Egyik faj esetében sem mutatkozott hatása a ládatakarításnak a lerakott tojások számában

Although clutch size was significantly different in the four colonies for Jackdaws and Red-footed Falcons, clutch size was not affected by nest-box cleaning in any of the three species (Table 3). The probability of an egg to develop into a fledged nestling was significantly higher for Kestrels breed- ing in cleaned nest-boxes than for those in uncleaned ones, while in case of Red-footed Falcons it was similar in both box types (Table 4, Figure 2). When partitioning this probability to hatching and fledging success we found a near significant trend in lower hatching probability in uncleaned boxes 


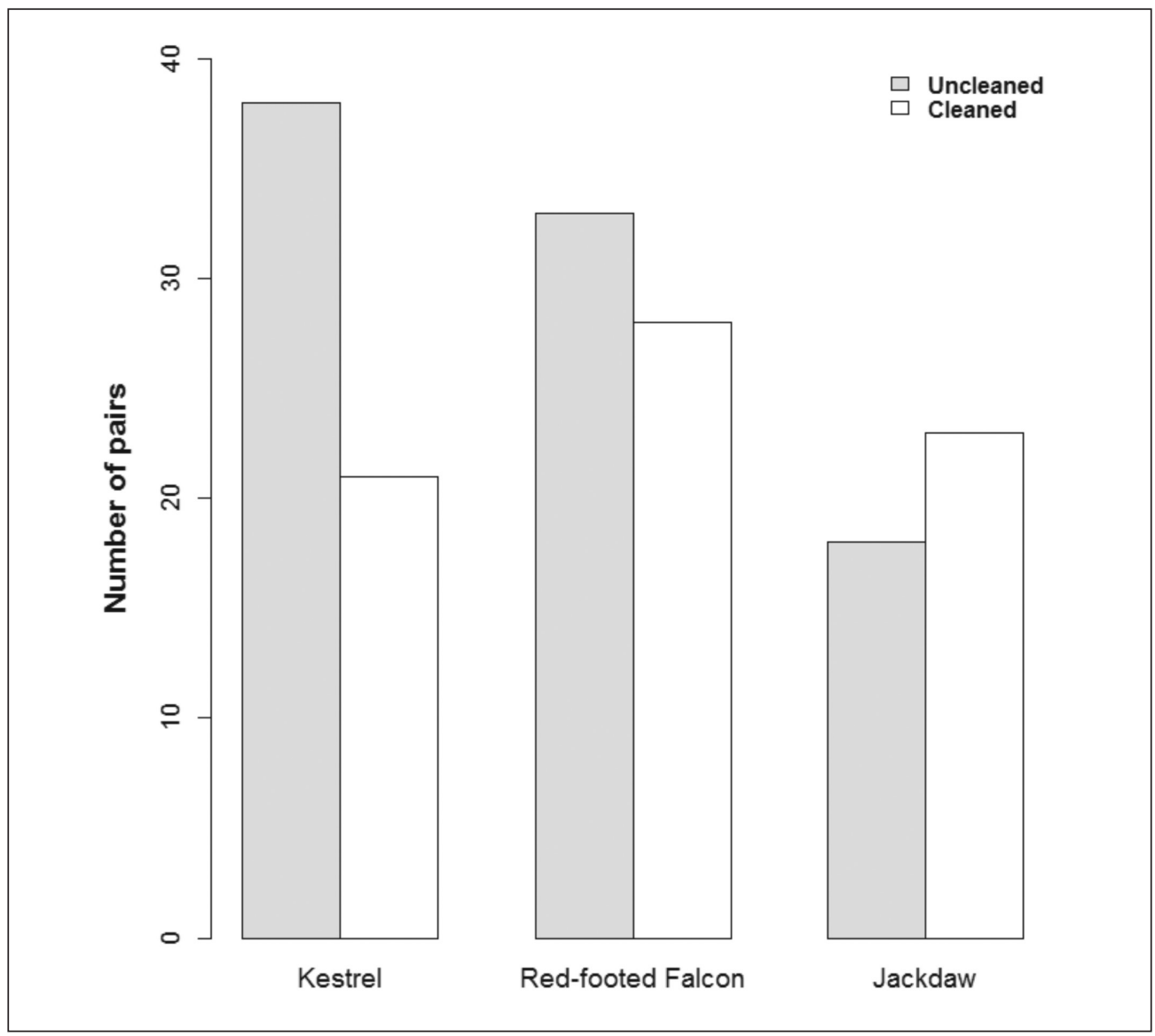

Figure 1. Number of breeding pairs of the three studied species in cleaned and uncleaned nestboxes. Kestrels occupied significantly more uncleaned boxes, while Red-footed Falcons and Jackdaws did not differentiate between the two groups

1. ábra A három vizsgált faj párjainak száma a takarított és a takarítatlan ládákban. A vörös vércsék szignifkánsan magasabb arányban foglalták a nem takarított ládákat, azonban a kék vércsék és csókák hasonló arányban használták a két ládatípust

(Binomial GLM, Effect of cleaning: 0.58, $\mathrm{SE}: 0.3, \mathrm{z}$-value $=1.9, \operatorname{Pr}(>|\mathrm{z}|)=0.056)$, but not in fledging success (Binomial GLM, Effect of cleaning: 1.35, SE:1.15, z-value=1.16, $\operatorname{Pr}(>|z|)=0.24)$. We identified 28 individually marked Red-footed Falcons breeding in the focal nest-boxes, however age structure of these birds was similar in the two nestbox groups (Mann-Whitney $\mathrm{U}$ test; $\mathrm{U}=51.5$, $\mathrm{p}=0.36$ ). A total of 90 Red-footed Falcons fledged from the focal boxes. Nest-box cleaning did not influence their body mass residuals or wing feather growth residuals (Table 5).

\section{Discussion}

In general, our results show that the nestbox cleaning affected only Kestrel settlement decisions and reproductive output. Albeit, giving a somewhat different re- 


\begin{tabular}{|l|c|c|c|c|c|}
\hline Species & N & Estimate & SE & z-value & p-value \\
\hline Kestrel & $37 / 21$ & 0.77 & 0.32 & 2.43 & 0.01 \\
\hline Red-footed Falcon* & $30 / 27$ & -0.67 & 0.45 & -1.47 & 0.14 \\
\hline
\end{tabular}

*significant effect of colony identity

Table 4. Binomial GLM parameter estimates fitted on the probability of fledging success. $\mathrm{N}$ denotes the number of clutches in uncleaned/cleaned nest-boxes. Kestrel eggs were significantly more likely to yield in fledged nestlings from cleaned boxes than those from uncleaned ones, while this pattern was absent for Red-footed Falcons

4. táblázat Binomiális GLM paraméter becslései a repítési sikerre. Az N a költések száma a takarítatlan/takarított ládákban. A vörös vércsék tojásai szignifikánsan magasabb arányban eredményeztek kirepült fiókákat a takarított, mint a takarítatlan ládákban, míg a kék vércsék esetében nem találtunk hasonló mintázatot

\begin{tabular}{|l|c|c|c|c|}
\hline Category & Estimate & SE & t-value & p-value \\
\hline \multicolumn{5}{|c|}{ Body mass (g) } \\
\hline Uncleaned & 0.03 & 2.62 & 0.01 & 0.98 \\
\hline Cleaned & 1.03 & 3.91 & 0.26 & 0.79 \\
\hline \multicolumn{5}{|c|}{ Wing length (mm) } \\
\hline Uncleaned & 0.34 & 1.67 & 0.2 & 0.83 \\
\hline Cleaned & -1.17 & 2.52 & -0.46 & 0.64 \\
\hline
\end{tabular}

Table 5. LME parameter estimates on the residuals of body mass and wing length of Red-footed Falcon nestlings. Neither response variable was significantly different between cleaned and uncleaned nest-boxes

5. táblázat A ládatakarításnak a kék vércse fiókák tömeg és szárnyhossz reziduálisaira gyakorolt hatását leíró LME modellek paraméter becslései. Egyik függő változó esetében sem találtunk szignifikáns hatást

sponse, our results seemingly corroborate the findings that Kestrels may cue on the presence of nest-material in boxes and select for boxes where previous breeding can be visually confirmed (Sumasgutner et al. 2014). However, we found no evidence that egg laying date between the two nest-box groups would be significantly different. It has to be also noted that assessing egg laying date was only possible for a fraction of the clutches reducing sample size considerably. Mean clutch size was also similar, indicating that once the settlement decisions were made, Kestrels did not adjust their initial parental investment to nest-box treatment. These decisions are presumably governed by other factors such as age, habitat quality, or prey availability (Sumasgutner et al. 2014).

In a colony where all nests have similar surrounding foraging habitats, the value of information on habitat quality of previous breeding attempts in a particular nest is negligible. Rather, it is probably more reliable to assess future ectoparasitic load on nestlings. Despite this, Kestrels clearly opted for uncleaned boxes contradicting previous assumptions. Kestrels are mostly territorial breeders in central Europe and have only recently started to breed in artificial 


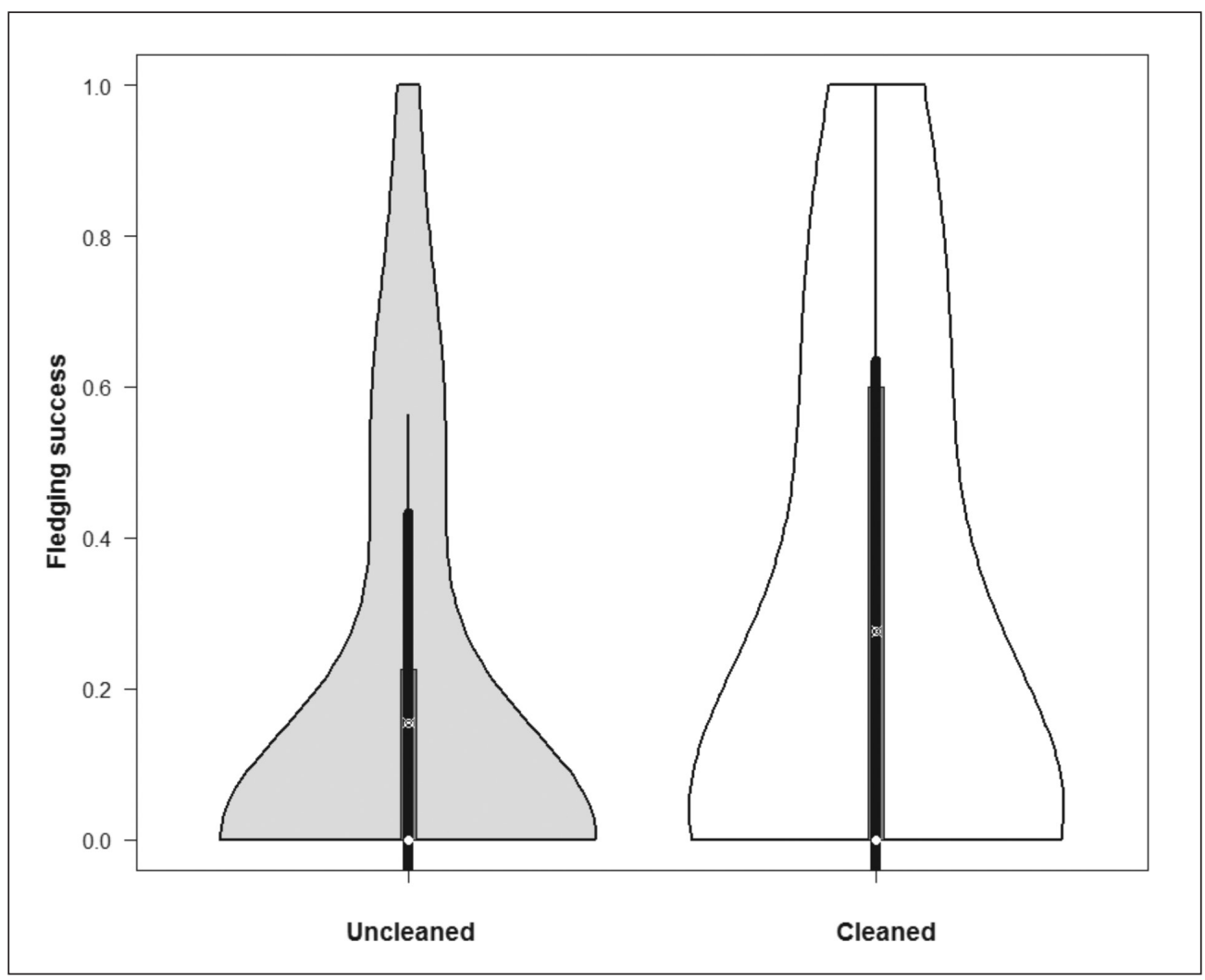

Figure 2. Violin plots (box and whisker plots with distribution densities on both sides) on Kestrel overall fledging success in cleaned and uncleaned nest-boxes. Kestrel eggs in cleaned nestboxes were significantly more likely to develop into fledged nestlings in cleaned nest-boxes

2. ábra A hegedű ábrán a vörös vércsék költési sikerének átlag és medián értékei láthatóak, a függőleges vastag vonal a középső 50\%-nyi adatot jelöli, oldalt az adatok simított hisztogramja található. A takarított ládákban a vörös vércse tojások szignifikánsan magasabb aránya eredményezett sikeresen kirepülő fiókát, mint a takarítatlan ládákban

nest-box colonies. Potentially, birds are maladapted to this situation as they had not developed mechanisms to correctly evaluate breeding site quality in colonies. They appear to rely on cues that would be of value in a territorial breeding setup. Dry hay, the substrate used in cleaned nest-boxes, differs in texture from the usual nest bedding, presenting a previously seldom seen novelty. It is likely that Kestrels - instead of selecting for uncleaned boxes - simply avoided this novel substrate. The probability of an egg to develop into a fledged nestling was significantly lower in uncleaned boxes. However, there was weak indication that this loss is more likely to occur as hatching failure rather than the loss of nestlings, suggesting that it is less likely to be caused by the negative effect of ectoparasites on nestlings. It is also possible, that increased ectoparasite load had an effect on incubating adults. Increased ectoparasite infestation could drive the birds to allocate more time into preening instead of incubation, result- 
ing in the observed lower hatching rate. However, the phenology of Carnus Fly load in Kestrel, Starling (Sturnus vulgaris) and Barn Owl (Tyto alba) clutches are linked to nestling age, showing that the parasites optimize their life cycle to nesting hosts rather than the adults (Roulin 1998, 1999, Liker et al. 2001, Kal'avský \& Pospíšilová 2010). In general, occupation rate and breeding success was relatively low in the study year (see Kotymán et al. 2015), presumably due to above average precipitation frequency and quantity throughout the breeding season. We used semi-closed nest-boxes providing shelter against rainfall, however, the large opening on the front does not completely keep the clutch dry (pers. obs). The pellet bedding in uncleaned boxes is predominantly a layer of compressed fur and various other prey remnants that may get sogged by rainfall or in highly humid air. It is possible that the lower probabilities of fledging derive from the different insulation properties of nest-materials rather than other factors.

We were unable to detect any significant effect of nest-box cleaning on the occupation rate and egg laying date of Red-footed Falcons and Jackdaws, indicating that they show no preference for cleaned boxes. Moreover, the lack of difference in clutch size indicates that the initial parental investment of females was not affected by nestbox cleaning. The natural breeding sites of Red-footed Falcons are predominantly rookeries, where the majority of nests are rebuilt annually (Horváth et al. 2015). Thus, cueing on previous usage of a given nest is less likely to be adaptive in choosing within colony breeding site. Nonetheless, the potential high parasite load deriving from uncleaned nest-box substrate may have an impact on nestling survival or con- dition. However, we found no supporting evidence for this.

Despite their wide use as effective tools in reducing nest site shortage, nest-boxes increase ectoparasite load in a wide range of avian systems (Valkama \& Korpimäki 1999, Fargallo et al. 2001, Wesołowski \& Stańska 2001, Lambrechts et al. 2012). Populations that depend on such artificial nest-sites are considered unsustainable on a long-temporal scale as preserving these sites needs constant maintenance that entail refurbishing, replacing, and cleaning of the boxes. This latter activity, however, is simply based on the assumption that ectoparasites accumulate and thus reduce population viability. Blood-sucking nest-dwelling ectoparasites can have various effects on avian broods, they may increase nestling mortality (Richner et al. 1993), decrease condition (Hoi et al. 2010), increase physiological stress (Martínez-Padilla et al. 2004), or influence parental food provisioning (Avilés et al. 2009, Johnson \& Albrecht 1993). In case of raptors, there is increasing evidence that brood size and nestling survival are less likely to be influenced by common blood-sucking parasites on a population level (Dawson \& Bortolotti 1997, Kal'avský \& Pospíšilová 2010), despite their high potential prevalence on nestlings. These results taken together with our findings are intriguing, and may have direct applicability in allocating nature conservation efforts, as they suggest that nestbox maintenance works do not necessarily need to include regular cleaning. However, nest-dwelling ectoparasites have various other effects on individual condition that may affect both parents and offspring and, thus, we urge further investigations that allow deeper inference of effects before decisions should be made. In case of the 
Red-footed Falcons in the Carpathian Basin, where the bulk of the pairs use artificial nest-sites (Palatitz et al. 2015), the effect of a potential excess parasite load in the boxes may have hidden yet influential ramifications on a population level.

\section{References}

Aparicio, J. M., Bonal, R. \& Muñoz, A. 2007. Experimental test on public information use in the colonial Lesser Kestrel. - Evolutionary Ecology 21(6): 783-800. DOI: 10.1007/s10682-006-9151-7

Arlt, D. \& Pärt, T. 2007. Nonideal breeding habitat selection: a mismatch between preference and fitness. - Ecology 88(3): 792-801. DOI: 10.1890/06-0574

Avilés, J. M., Pérez-Contreras, T., Navarro, C. \& Soler, J. J. 2009. Male Spotless Starlings adjust feeding effort based on egg spots revealing ectoparasite load. - Animal Behaviour 78(4): 993-999. DOI: 10.1016/j.anbehav.2009.07.020

Boulinier, T., McCoy, K. D., Yoccoz, N. G., Gasparini, J. \& Tveraa, T. 2008. Public information affects breeding dispersal in a colonial bird: Kittiwakes cue on neighbours. - Biology Letters 4(5): 538540. DOI: $10.1098 / \mathrm{rsbl} .2008 .0291$

Brake, I. 2011. World catalog of the family Carnidae (Diptera, Schizophora). - Contributions to the Systema Dipterorum (Insecta: Diptera) Myia 12: 113169. DOI: $10.4289 / 082.115 .0102$

Brown, C. R. \& Brown, M. B. 1986. Ectoparasitism as a cost of coloniality in Cliff Swallows (Hirundo pyrrhonota). - Ecology 67(5): 1206-1218. DOI: $10.2307 / 1938676$

Brown, C. R. \& Brown, M. B. 2004. Empirical measurement of parasite transmission between groups in a colonial bird. - Ecology 85(6): 1619-1626. DOI: 10.1890/03-0206

Calabuig, G., Ortego, J., Cordero, P. J. \& Aparicio, J. M. 2010. Colony foundation in the Lesser Kestrel: patterns and consequences of the occupation of empty habitat patches. - Animal Behaviour 80(6): 975-982. DOI: 10.1016/j.anbehav.2010.08.016

Capelle, K. J. \& Whitworth, T. L. 1973. The distribution and avian hosts of Carnus hemapterus (Diptera: Milichiidae) in North America. - Journal of Medical Entomology 10(5): 525-526. DOI: 10.1093/jmedent/10.5.525

Danchin, E., Giraldeau, L. A., Valone, T. J. \& Wagner, R. H. 2004. Public information: from nosy neighbors to cultural evolution. - Science 305(5683): 487. DOI: $10.1126 /$ science. 1098254

Danchin, E. \& Wagner, R. H. 1997. The evolution of

\section{Acknowledgements}

We thank all volunteers whom contributed to field work and data collection. This project was funded by HU-SRB IPA CBC (HU-SRB 0901/122/120) and LIFE11/NAT/HU/000926 project.

coloniality: the emergence of new perspectives. Trends in Ecology \& Evolution 12(9): 342-347. DOI: $10.1016 / \mathrm{S} 0169-5347(97) 01124-5$

Dawson, R. D. \& Bortolotti, G. R. 1997. Ecology of parasitism of nestling American Kestrels by Carnus hemapterus (Diptera: Carnidae). - Canadian Journal of Zoology 75(12): 2021-2026. DOI: $10.1017 /$ S0031182015000037

Espie, R. H., James, P. C., Oliphant, L. W., Warkentin, I. G. \& Lieske, D. J. 2004. Influence of nest-site and individual quality on breeding performance in Merlins Falco columbarius. - Ibis 146(4): 623631. DOI: $10.3161 / 000164514 X 682841$

Faraway, J. J. 2006. Extending the linear model with $\mathrm{R}$ : generalized linear, mixed effects and nonparametric regression models. - Chapman \& Hall/ CRC Boca Raton, Florida, pp. 312 DOI: 10.1007/ s00180-009-0152-1.

Fargallo, J. A., Blanco, G., Potti, J. \& Viñuela, J. 2001. Nestbox provisioning in a rural population of Eurasian Kestrels: breeding performance, nest predation and parasitism. - Bird Study 48(2): 236-244. DOI: $10.1007 / \mathrm{s} 00265-014-1808-6$

Hoi, H., Krištofík, J., Darolová, A. \& Hoi, C. 2010. Are parasite intensity and related costs of the milichiid fly Carnus hemapterus related to host sociality? - Journal of Ornithology 151(4): 907-913. DOI: 10.1007/s00265-014-1808-6

Horváth, É., Solt, S., Kotymán, L., Palatitz, P., Piross, S. I. \& Fehérvári, P. 2015. Provisoning nest material for Rooks, a potential tool for conservation management. - Ornis Hungarica 23(1): 22-31. DOI: 10.1515/orhu-2015-0002

Johnson, L. S. \& Albrecht, D. J. 1993. Effects of Haematophagous ectoparasites on nestling House Wrens, Troglodytes aedon: Who pays the cost of parasitism? - Oikos 66(2): 255-262. DOI: $10.2307 / 3544812$

Kal'avský, M. \& Pospíśilová, B. 2010. The ecology of ectoparasitic species Carnus hemapterus on nestlings of Common Kestrel (Falco tinnunculus) in Bratislava. - Slovak Raptor Journal 4: 45-48. DOI: $10.2307 / 3544812$

Kasprzykowski, Z. 2008. Nest location within the tree and breeding parameters of Rooks Corvus 
frugilegus : the position of a nest in the tree influences some parameters of reproduction. - Bird Study 55(1): 59-65. DOI: 10.1080/00063650809461505

Kotymán, L., Solt, S., Horváth, É., Palatitz, P. \& Fehérvári, P. 2015. Demography, breeding success and effects of nest type in artificial colonies of Red-footed Falcons and allies. - Ornis Hungarica 23(1): 1-21. DOI: 10.1515/orhu-2015-0001

Lambrechts, M. M., Wiebe, K. L., Sunde, P., Solonen, T., Sergio, F., Roulin, A., Exo, K.-M. 2012. Nest box design for the study of diurnal raptors and owls is still an overlooked point in ecological, evolutionary and conservation studies: a review. - Journal of Ornithology 153(1): 23-34. DOI: 10.1007/s10336-011-0720-3

Liker, A., Márkus, M., Vozár, Á., Zemankovics, E. \& Rózsa, L. 2001. Distribution of Carnus hemapterus in a Starling colony. - Canadian Journal of Zoology 79(4): 574-580. DOI: 10.1139/z01-018.

Mainwaring, M. C. 2015. The use of man-made structures as nesting sites by birds: A review of the costs and benefits. - Journal for Nature Conservation 25:17-22. DOI: 10.1016/j.jnc.2015.02.007

Martínez-Padilla, J., Martínez, J., Dávila, J. A., Merino, S., Moreno, J. \& Millán, J. 2004. Within-brood size differences, sex and parasites determine blood stress protein levels in Eurasian Kestrel nestlings. - Functional Ecology 18(3): 426-434. DOI: 10.1111/j.0269-8463.2004.00874.x

Ontiveros, D., Caro, J. \& Pleguezuelos, J. M. 2008. Possible functions of alternative nests in raptors: the case of Bonelli's Eagle. - Journal of Ornithology 149(2): 253-259. DOI: 10.1007/s10336-007-0268-4

Palatitz, P., Fehérvári, P., Solt, Sz. \& Horváth, É. 2015. Breeding population trends and pre-migration roost site survey of the Red-footed Falcon in Hungary. - Ornis Hungarica 23(1): 77-93. DOI: 10.1515/orhu-2015-0007

Parejo, D. 2004. The heterospecific habitat copying hypothesis: can competitors indicate habitat quality? - Behavioral Ecology 16(1): 96-105. DOI: 10.1093/beheco/arh136

Penteriani, V., Balbontin, J. \& Ferrer, M. 2003. Simultaneous effects of age and territory quality on fecundity in Bonelli's Eagle Hieraaetus fasciatus. - Ibis 145(2): E77-E82. DOI: 10.1046/j.1474919X.2003.00159.x

Pinheiro, J. C. \& Bates, D. M. 2000. Mixed-effects models in S and S-PLUS. - Springer-Verlag New York, pp. 528 DOI: 10.1198/jasa.2001.s411.

R Core Team. 2015. R: A language and environment for statistical computing. - R Foundation for Statistical Computing Vienna, Austria, Retrieved from http://www.R-project.org/

Richner, H., Oppliger, A. \& Christe, P. 1993. Effect of an ectoparasite on reproduction in Great Tits. Journal of Animal Ecology 62(4): 703-710. DOI: $10.2307 / 5390$

Roulin, A. 1998. Cycle de reproduction et abondance du diptère parasite Carnus hemapterus dans les nichées de chouettes effraies Tyto alba [Reproductive cycle and abundance of Carnus hemapterus a parasitic diptereae in Barn Ownl Tyto alba broods]. - Alauda 66(4): 265-272. (in French with English Summary)

Roulin, A. 1999. Fécondité de la mouche Carnus hemapterus, ectoparasite des jeunes Chouettes effraies Tyto alba [Fecundity of Carnus hemapterus (Diptera), an ectoparasite of juvenile Barn Owls Tyto alba]. - Alauda 67(3): 205-212. (in French with English Summary)

Roulin, A., Brinkhof, M. W. G., Bize, P., Richner, H., Jungi, T. W., Bavoux, C. \& Burneleau, G. 2003. Which chick is tasty to parasites? The importance of host immunology vs. parasite life history. - Journal of Animal Ecology 72(1): 75-81. DOI: 10.1046/j.1365-2656.2003.00677.x

Rózsa, L., Rékási, J. \& Reiczigel, J. 1996. Relationship of host coloniality to the population ecology of avian lice (Insecta: Phthiraptera). - Journal of Animal Ecology 65(2): 242-248. DOI: 10.2307/5727

Serrano, D., Oro, D., Ursúa, E. \& Tella, J. L. 2005. Colony size selection determines adult survival and dispersal preferences: Allee effects in a colonial bird. - The American Naturalist 166(2): 22-31. DOI: $10.1086 / 431255$

Serrano, D. \& Tella, J. L. 2007. The role of despotism and heritability in determining settlement patterns in the colonial Lesser Kestrel. - The American Naturalist 169(2): E53-E67. DOI: 10.1086/510598

Sumasgutner, P., Vasko, V., Varjonen, R. \& Korpimäki, E. 2014. Public information revealed by pellets in nest sites is more important than ecto-parasite avoidance in the settlement decisions of Eurasian Kestrels. - Behavioral Ecology and Sociobiology 68(12): 2023-2034. DOI: 10.1007/s00265-014-1808-6

Tripet, F. \& Richner, H. 1997. Host responses to ectoparasites: food compensation by parent Blue Tits. - Oikos 78(3): 557-561. DOI: 10.2307/3545617.

Valkama, J. \& Korpimäki, E. 1999. Nestbox characteristics, habitat quality and reproductive success of Eurasian Kestrels. - Bird Study 46(1): 81-88. DOI: 10.1080/00063659909461117

Wesołowski, T. \& Stańska, M. 2001. High ectoparasite loads in hole-nesting birds - a nestbox bias? - Journal of Avian Biology 32(3): 281-285. DOI: 10.1111/j.0908-8857.2001.320313.x

Wimberger, P. H. 1984. The use of green plant material in bird nests to avoid ectoparasites. - The Auk 101(3): 615-618. DOI: 10.1098.rsbl.2012.0931 